\title{
Exploring the Motivation of English Language Learning Students in Indonesia
}

\author{
Zakir Hussain Radfar*, Nenden Sri Lengkanawati \\ English Education Department \\ Universitas Pendidikan Indonesia \\ Bandung, Indonesia \\ *zakir.radfar1@gmail.com, Nendensl@upi.edu
}

\begin{abstract}
Motivation is an essential part of the learning process especially learning a language to achieve the desired goals. This study aims to examine the English major first-year students' motivation for learning English. The method employed in this study is a case study method. The participants were 50 students from the English Department at Indonesia University of Education. The questionnaire was used as the instrument to collect the data. The findings revealed that including having significant differences between integrative and instrumental motivation, students' motivation in learning English is high. Besides, students are more instrumentally motivated than integrative motivation. Hence, teachers should increase the students' integrative motivation through raising their interests in the culture of the target language, such as giving information about people and lifestyle, geography, literature of the English countries through visual and even organizing group sharing for learners who have been to English speaking countries.
\end{abstract}

Keywords: integrative motivation, instrumental motivation, English learning

\section{INTRODUCTION}

Motivation is an essential part of the learning process. It contributes to many parts of learning, such as achieving the desired goals [1]. In language learning, it is one of the most important factors for students to be successful [2]. Therefore, motivation has a big impact on the success of learning a language. Gilakjani, Leong, and Sabouri confirms that in EFL settings, there is insufficient English input in the environment around learners and probably there are not enough opportunities for interaction with English speakers and limited models promoting the learning of English, and there may not be widespread enough social acceptance for the idea of becoming proficient in English [3]. That is why EFL students need the motivation to drive them to learn a language.

Moreover, there are two types of motivation i.e., integrative and instrumental motivation. Instrumental motivation refers to the learners' desire to learn a language for their purposes such as employment or travel, whereas integrative motivation refers to the desire to learn a language to integrate successfully into the target language community. Furthermore, Gardner claims (as cited in Khodashenas, et al. [4], that an integratively motivated learner shows interest in learning about the culture and the people of the target language, whereas an instrumentally motivated learner has more pragmatic considerations in his/her mind regarding L2 learning, such as obtaining a job, or gaining more money.

In Indonesia, English is taught as a foreign language, and for several decades, it has been a problem to be taught well for students at different levels [5]. Besides, students who are studying English still have low motivation and lead to be low achievement without deeply clarifying the causes [2]. Based on students' learning differences and background, they come to the class only for being taken attendance. Many of them are passive in the teaching and learning process because they are shy to speak English. Only some are brave to communicate in English. Thus, motivation is the key determinant of frequency and type of strategy. It affects how determined learners are willing to learn a language and how much they will persevere when they are challenged. Hence, motivation should be maximized among students because without motivation, learning a language is hard to be successful.

As a result, the first-year students' motivation should be investigated since they possess a high level of proficiency and they achieved to be accepted to the English Department. Therefore, the present study intends to highlight the motivation of first-year students at Indonesia University of Education. It will reveal the students' level of motivation in learning English. Besides, it will expose the types of motivation that students are motivated in learning English. Ahmadi and Aliakbari found that exciting and proficient teachers, interesting learning context, focus on speaking and better textbooks made students more motivated in learning the English language [6]. Besides, Al-Tamimi and Shuib found that interest in the culture of the English speaking world as represented by English-language films makes motivated students learn English [7]. Thus, the result of this study will yield some useful insights to reform teachers' education and professional development and teachers have to sustain and maintain a better strategy to motivate students. This study aims to answer the following questions.

To what extent is the student's motivation in English language learning? 
- Which motivation is more dominant between integrative and instrumental motivation?

\section{MethodOLOGY}

This research was a descriptive study using a case study method [8]. The integrative and instrumental motivation models questionnaire adapted from Gardner and Lambart was utilized as the instrument to collect the data [9]. The study involved 50 undergraduate students of English Education major which were selected by using purposive sampling. Students who were involved in this study were undergraduate students with a high level of English proficiency.

In this study, the data was collected using the integrative and instrumental motivation models questionnaire adapted from Gardner and Lambart [9]. The instrument was originally in English so that it was translated into the Indonesian language. In the questionnaire, there are two parts and 25 questions consisting items related to integrative motivation (1-12) and those related to instrumental motivation (13-25). A five-point Likert-scale was used in this study from 1 strongly disagree to 5 strongly agree. Moreover, students were informed that the information they gave would be kept confidentially, and be used for research purpose only.

The data were analysed by using SPSS version 16.0 to determine the mean, standard deviation, and the difference between integrative and instrumental motivation of students.

\section{RESULTS AND DISCUSSION}

Below is the mean and deviation standard from all the questionnaire results.

TABLE I. Student's Motivation MeAn AND DeViation STANDARD

\begin{tabular}{|l|l|l|}
\hline & \multicolumn{1}{|c|}{ MEAN } & SD \\
\hline MOTIVATION & 3,98 & 0,35 \\
\hline
\end{tabular}

Based on Table 1, it showed that students' motivation for learning English is high (3.98). It is common because every student must have high motivation so they choose to enrol as English students in the university. According to this, other researchers' investigation showed the same result as Ahmadi. [10], Aliakbari and Ahmadi, [6] and Vaezi, [11]. In these researches, students are motivated because they think that English can help them get a good job, use the internet, read books, know people from different parts of the world, and communicate easily with other people and cultures through English, to meet varied people and to appreciate English art and literature. But the point is not about high or low but what kind of motivation they have and what motivated them most. As was stated before, the questionnaire was divided into integrative and instrumental motivation. Below is the result of each motivation.
TABLE II. DESCRIPTIVE Statistics OF InTEGRATIVE Motivation $(\mathrm{N}=50)$

\begin{tabular}{|l|l|l|l|l|l|l|l|}
\hline Items & \multicolumn{1}{|c|}{$\mathbf{1}$} & $\mathbf{2}$ & $\mathbf{3}$ & $\mathbf{4}$ & $\mathbf{5}$ & $\mathbf{M}$ & SD \\
\hline Q1 & 0 & 0 & 0 & 15 & 35 & 4,70 & 0,46 \\
\hline Q2 & 0 & 0 & 0 & 19 & 31 & 4,62 & 0,49 \\
\hline Q3 & 0 & 0 & 12 & 22 & 16 & 4,08 & 0,75 \\
\hline Q4 & 0 & 1 & 14 & 29 & 6 & 3,80 & 0,67 \\
\hline Q5 & 0 & 3 & 14 & 21 & 12 & 3,84 & 0,87 \\
\hline Q6 & 0 & 2 & 22 & 16 & 10 & 3,68 & 0,84 \\
\hline Q7 & 0 & 8 & 32 & 7 & 3 & 3,10 & 0,74 \\
\hline Q8 & 0 & 0 & 10 & 25 & 15 & 4,10 & 0,71 \\
\hline Q9 & 0 & 0 & 3 & 27 & 20 & 4,34 & 0,59 \\
\hline Q10 & 1 & 1 & 15 & 25 & 8 & 3,74 & 0,83 \\
\hline Q11 & 0 & 2 & 36 & 12 & 0 & 3,18 & 0,52 \\
\hline Q12 & 0 & 2 & 44 & 4 & 0 & 3,02 & 0,38 \\
\hline \multicolumn{7}{|l|}{ Overall mean score } \\
\hline
\end{tabular}

Based on Table 2 above, the students' integrative motivation is high $(\mathrm{M}=3$. 85). Comparison between the mean scores of the questions in the integrative part illustrated that students were strongly motivated in questions $1,2,3,8$ and 9. Therefore, they believe that; 1 . They need to learn English because they can be more ease with people who speak English, 2. They can meet and converse with more varied people, 3 . They can understand English art and literature, 8. They can know the various culture, and 9. Keep in touch with foreign people. Amazingly, these all questions reveal that most students are interested in having interaction with native speakers and their culture, thereby, the instructors need to help students to understand the study of another language and culture can only enhance their perception and understanding of other cultures.

Teachers can provide students to interact with English native speaker (for example by invite foreigner to attend the class) and show them various art and cultures through video or any other media that is available. Besides, the result can help the teacher in seeking alternative ways on how to motivate students in lower grades, for instance, Teachers can likely restructure the teaching and learning environment by providing different strategies to students, finding ways to motivate students to learn and engage them in active learning. Understanding students' learning style and other factors like learning strategies and motivation that influence students learning to enable teachers to develop the most appropriate ways of interacting with their students in and out of the classroom.

TABLE III. DESCRIPTIVE STATISTICS OF INSTRUMENTAL MOTIVATION $(\mathrm{N}=50)$

\begin{tabular}{|l|l|l|l|l|l|l|l|}
\hline Items & $\mathbf{1}$ & $\mathbf{2}$ & $\mathbf{3}$ & $\mathbf{4}$ & $\mathbf{5}$ & $\mathbf{M}$ & SD \\
\hline Q13 & 0 & 0 & 0 & 12 & 38 & 4,76 & 0,43 \\
\hline Q14 & 0 & 0 & 3 & 21 & 26 & 4,44 & 0,64 \\
\hline Q15 & 0 & 0 & 1 & 15 & 34 & 4,66 & 0,52 \\
\hline Q16 & 2 & 4 & 12 & 26 & 6 & 3,60 & 0,95 \\
\hline Q17 & 0 & 0 & 3 & 28 & 19 & 4,32 & 0,59 \\
\hline Q18 & 0 & 0 & 4 & 21 & 25 & 4,42 & 0,64 \\
\hline Q19 & 0 & 1 & 16 & 23 & 10 & 3,84 & 0,77 \\
\hline Q20 & 0 & 1 & 11 & 24 & 14 & 4,02 & 0,77 \\
\hline Q21 & 0 & 4 & 21 & 19 & 6 & 3,54 & 0,81 \\
\hline Q22 & 0 & 0 & 6 & 24 & 20 & 4,28 & 0,67 \\
\hline Q23 & 0 & 0 & 5 & 24 & 21 & 4,32 & 0,65 \\
\hline Q24 & 0 & 0 & 3 & 26 & 21 & 4,36 & 0,60 \\
\hline Q25 & 9 & 11 & 20 & 8 & 2 & 2,68 & 1,06 \\
\hline \multicolumn{7}{|l}{ Overall mean score } \\
\hline
\end{tabular}


It means student's instrumental motivation is significantly higher than integrative motivation. In this case, teachers can trigger students' motivation through instrumental motivation more than integrative motivation. Bear in mind, it doesn't mean integrative motivation is less important than instrumental motivation. The most important is to promote enough motivation so students will learn English better. Motivating student's necessary to ensure learners' academic growth and Encouragement can make learning more efficient and improve the classroom atmosphere.

\section{CONCLUSIONS}

In conclusion, the motivation of students in English language Department is high. Besides, they are instrumentally motivated than integrative motivation $(4.10>3.85)$. There is a significant difference between integrative and instrumental motivation, which means students are significantly higher in instrumental motivation than integrative motivation. Therefore, teachers can increase the students' integrative motivation through raising their interests in the culture of the target language, such as giving information about people and lifestyle, geography, literature of the English countries through visual and even organizing group sharing for learners who have been to English speaking countries. Including these all, environment, material, classrooms, social context, facilities, parents and peers have their impact and influence on the motivation of students. However, Teachers have to sustain and maintain a better strategy to motivate students.

\section{REFERENCES}

[1] A. Rehman, H. A. Bilal, A. Sheikh, N. Bibi, .\& A. Nawaz, "The Role of Motivation in Learning English Language for Pakistani Learners," International Journal ofHumanity and Social Science, 2014.

[2] K. Mattarima, and A.R. Hamdan, Learners' Motivation and Learning Strategies in English Foreign Language (EFL) in Indonesian Context, Journal of Edupres, 1. 2011

[3] A.P. Gilakjani, L. Leong, N.B. Sabouri, A Study on the Role of Motivation in Foreign Language Learning and Teaching, I. J. Modern Education and Computer Science, 7, 2012.

[4] M.R. Khodashenas, E. Amouzegar, S.K. Farahani, S.G.H. Hasheminasab and V. Kazemian, "Review article: Role of motivation in language Learning," International Journal of Applied and Basic Science, vol. 6 , no. 6, 2013 .

[5] B. Musthafa, Teaching English to Young Learners in Indonesia: Essential Requirements, Educationist vol. 4, no. 2, 2010.

[6] S. Ahmadi, and M. Aliakbari, "English Learning Motivation: The Case Study of Female Students in Ilam, Iran," International Journal of Psychology and Behaviour Research vol. 3, no. 6, 2014.

[7] A. Al-Tamimi and M. Shuib, "Motivation and Attitudes towards Learning English: A Study Of Petroleum Engineering Undergraduates At Hadhramout University Of Sciences And Technology," GEMA Online Journal of Language Studies 9(02), 2009

[8] M. Bassey, Case Study Research in Educational Setting. Open University Press. Philadelphia, USA. 1999.

[9] R.C. Gardner, (Gardner and Lambert (1959): Fifty Years and Counting1), Canadian Association of Applied Linguistic. Ottawa 2009.

[10] M.R. Ahmadi, The effect of integrative and instrumental motivation on Iranian EFL learners 'language students, ELT VOICE INDIA, 22309136. 2011.

Table 4 above showed that there is a significant difference between integrative and instrumental motivation.
[11] Z. Vaezi, Language Learning Motivation Among Iranian Undergraduate Students, World Applied Science Journal, vol. 5, no. 1, 2008. 